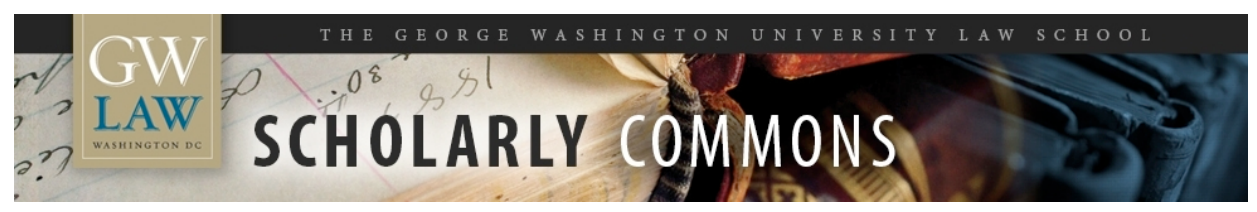

\title{
Introduction: The Promise and Perils of Innovation in Cross- Border Procurement
}

\author{
Christopher R. Yukins \\ George Washington University Law School, cyukins@law.gwu.edu \\ Gabriella M. Racca \\ University of Turin
}

Follow this and additional works at: https://scholarship.law.gwu.edu/faculty_publications

Part of the Law Commons

\section{Recommended Citation}

Yukins, Christopher R. and Racca, Gabriella M., Introduction: The Promise and Perils of Innovation in Cross-Border Procurement (2019). Gabriella M. Racca \& Christopher R. Yukins, Introduction: The Promise and Perils of Innovation in Cross-Border Procurement, in Joint Public Procurement and Innovation: Lessons Across Borders (G. M. Racca - C. R. Yukins, eds.) (Bruylant, 2019).; GWU Law School Public Law Research Paper No. 2019-70; GWU Legal Studies Research Paper No. 2019-70. Available at SSRN: https://ssrn.com/abstract=3486897

This Book Part is brought to you for free and open access by the Faculty Scholarship at Scholarly Commons. It has been accepted for inclusion in GW Law Faculty Publications \& Other Works by an authorized administrator of Scholarly Commons. For more information, please contact spagel@law.gwu.edu. 


\title{
DROIT ADMINISTRATIF ADMINISTRATIVE LAW
}

\author{
27 \\ Joint Public Procurement \\ and Innovation \\ Lessons Across Borders
}

Editors and Scientific Directors:

Gabriella M. Racca

Professor at the University of Turin, Italy

Christopher R. Yukins

Professor at the George Washington University, USA

Scientific Committee

Jean-Bernard Auby - Professor Emeritus, Sciences Po, Paris, France

Roberto Cavallo Perin - Professor, University of Turin, Italy

Gian Luigi Albano - Head of Division, Consip S.p.A., Italy

Peter McKeen - Adjunct Professor, University of Virginia, USA 


\section{TABLE OF GONTENTS}

Foreword .......................................................................................... vii

Acknowledgements................................................................................. $\mathrm{xi}$

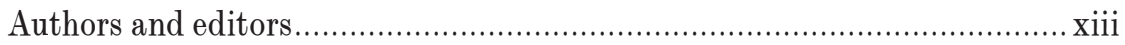

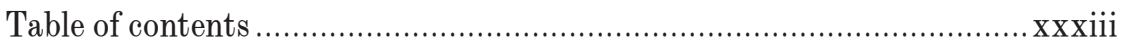

Introduction. The Promise and Perils of Innovation in Cross-Border

Procurement by Gabriella M. RACCA and Christopher R. YUkins.............. 1

Part I. Crossborder Procurement and Innovation .......................29

Chapter 1. Process Innovation Under the New Public

Procurement Directives by Ivo LocATELLI ........................................... 31

Chapter 2. Cooperative Purchasing: A US Perspective

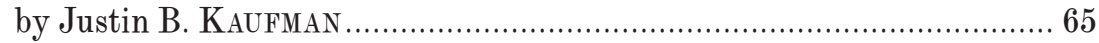

Chapter 3. European Joint Cross-border Procurement and Innovation by Roberto Cavallo Perin

and Gabriella M. RACCA................................................................... 93

Chapter 4. The Relevance of Promoting Collaborative

and Joint Cross Border Procurement

for Buying Innovative Solutions

by Patricia VAlCÁRCEL FernándeZ ....................................................... 133

Part II. Smart Cities and Procurement ......................................... 171

Chapter 5. Smartness and the Cities

by Giuseppe Franco Ferrari .................................................... 173

Chapter 6. Public Contracts and Smart Cities

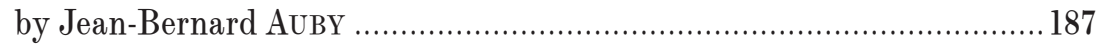

Chapter 7. Procurement and Smart Cities: Exploring Examples

on Both Sides of the Atlantic by Laurence FolLIOT-LALLIOT

and Peter T. McKenn.

Chapter 8. From Works Contracts to Collaborative Contracts:

The Challenges of Building Information Modeling (BIM)

BRUYLANT 
in public procurement by Giuseppe M. DI GIUDA

and Gabriella M. RACCA.

Part III. Encouraging Innovation 273

Chapter 9. Public Procurement as a Strategy for the Development of Innovation Policy by José Maria Gimeno Feliu

Chapter 10. State Aid and Procurement for Research, Development and Innovation by Bianca RACOLṬA and Dacian C. Dragos

Chapter 11. The U.S. Small Business Innovation Research (SBIR) Program: A Comparative Assessment by Crystal Santerre-Funderburg and Christopher R. Yukins

Chapter 12. Innovation Partnerships: Purpose, Scope of Application and Key Elements of a New Instrument of Strategic Procurement by Christoph KrönKE

Part IV. Innovation in the Procurement Process

Chapter 13. Innovation in the Evaluation of Public Procurement Systems by Lena Diesing and Paulo Magina

Chapter 14. The Pursuit of Streamlined Purchasing: Commercial Items, E-Portals, and Amazon by Peter T. McKeEn.

Chapter 15. Preliminary Market Consultations in Innovative Procurement: A Principled Approach and Incentives for Anticompetitive Behaviors by Antonio Miño LóPEZ.

Chapter 16. On the Non-tariff Barriers Obstructing Free Trade in the Transatlantic Defense Procurement Market by Daniel E. Schoeni.

Chapter 17. Electronic Means as an Approach to Public Purchasing by Matteo PignatTi

Chapter 18. A Qualitative Step from e-Communication to e-Procurement: the Estonian e-Procurement Model by Mari Ann Simovart and Marina Borodina 
Chapter 19. An overview of innovative procurement in Eastern Europe by Silvia Ponzio.

Chapter 20. The New Asian Development Bank

Procurement Policy and Regulations: Promoting Innovation in Public Procurement in Asia?

by Jellie M. MoLino

Chapter 21. Innovation in Public Procurements in the Egyptian PPP Legislation (With reference to PPP Legislation in Dubai and Kuwait) by Mohamed A. M. IsmaIL

Chapter 22. Autonomy and Innovation in Italian Regional Procurement: the Sicilian Case by Anna Romeo....

Chapter 23. Innovation in the Public Procurement Process in Armenia: A Strategy for EU Integration by Ani Asatryan. 


\title{
Introduction.
}

\section{The Promise and Perils of Innovation in Cross-Border Procurement}

BY

\author{
Gabriella M. RACCA \\ Professor of Administrative Law, University of Turin \\ Christopher R. Yukins \\ Professor of Government Procurement Law \\ The George Washington University Law School
}

This is a time of transition in procurement law, a time for new beginnings, and for rethinking old approaches in an increasingly globalized economy. Recognizing these enormous changes underway in our discipline, this volume seeks to capture some of the best ideas, from some of the leading academic writers and practitioners in our field.

\section{Innovation in Procurement: \\ Its Meanings, and How It Is Addressed in this Book}

This volume centers on 'innovation in procurement', which can mean many things. (1)

The first, of course, is the purchase of innovation: buying cutting-edge technology in public procurement markets.

A second meaning of 'innovation in procurement' is encouraging innovative suppliers in the procurement process.

A third meaning is innovation in the procurement process itself: new methods and approaches for the procurement process.

The book deals with all of them, and they are often variously mixed, as for example in the cases of the networks of Centralized Purchasing Bodies in the $\mathrm{EU}$ (which use innovative procurement measures to spur development), and the use of the Small Business Innovation Research (SBIR) program to advance

(1) See, e.g., P. Sмiтh, "Innovation Procurement - What Exactly Does It Mean?", Public Spend Forum, May 2017. 
technological innovation in the United States, a program which SanterreFunderburg and co-editor Yukins assess in their chapter.

While the EU and the U.S. landscapes for encouraging innovation in procurement are very different, the two systems' emerging issues and concerns are often the same.

Interestingly, the working EU definition for innovation, that is, the "implementation of a new marketing method, or a new organisational method in business practices, workplace organisation or external relations, inter alia, with the purpose of helping to solve societal challenges or to support the Europe 2020 strategy for smart, sustainable and inclusive growth," (2) is echoed in one of the generally accepted procurement goals in the U.S. federal administration, that is, to focus on 'innovative acquisition methods', with a view to new ways of doing things that can enhance performance.(3) According to the Office of Innovation and Technology in the U.S. city of Philadelphia, a subject of the analysis by Laurence Folliot-Lalliot and Peter McKeen in their chapter on procurement and smart cities, innovation focuses on "[d]eveloping and sustaining innovative technology practices within the City through engaging and empowering citizens, improving business processes, working collaboratively and constantly searching for new opportunities".(4) This book, therefore, tries to add value in the on-going debate on how public procurement across borders 'innovates' in what seems to be a common direction, regardless of jurisdiction.

\subsection{Purchase of innovation}

Purchasing new or significantly improved products, services or processes of production, building or construction is the first meaning of innovation in procurement. Several chapters in this book focus on the use of public procurement in obtaining "technologically-advanced and innovative products and services at better prices", more particularly, the chapters by Jean-Bernard Auby, Laurence Folliot-Lalliot and Peter McKeen, and Giuseppe Franco Ferrari on smart cities.(5)

Ferrari highlights the role of 'smartness in the cities' in the development of procurement regulations and policies, i.e., from an intelligent city to a future 'cyber-civic' city. He emphasizes the importance of enhancing the capacity of

(2) Art. 2, § 1(22), Dir. 2014/24/EU of the European Parliament and of the Council of 26 February 2014 on public procurement and repealing Dir. 2004/18/EC.

(3) S. Kelman, "Reinventing government, 25 years on: has the procurement system improved?", PPLR, 2018, 3, p. 101

(4) See L. Folliot Lalliot and P.T. McKeen, "Procurement and Smart Cities: Exploring Examples on Both Sides of the Atlantic", Chapter 7 in this book.

(5) See J.-B. Auby, "Public Contracts and Smart Cities"; L. Folliot Lalliot and P.T. McKeen "Procurement and Smart Cities: Exploring Examples on Both Sides of the Atlantic"; G.F. Ferrari, "Smartness and the Cities", Chapters 6, 7,5 in this book. 
a smart city to use artificial intelligence in the performance of its sociological function such as governance, attracting business, and even facilitating democratic processes for the establishment of innovative regulations, not only in government contracting but also in the advancement of the highest social and environmental protections.

Although Jean-Bernard Auby negates the presence of an exclusive definition for the 'smart cities' movement, he shares Ferrari's analysis on the phases of its implementation by asserting the role of a 'triple set of transformation' - transformation of infrastructures, the growing importance of digitalization and data, and changes in governance - in the evolution of smart cities. He claims that the transformation of the urban infrastructure ('meta-infrastructures'), digitization and data ('smart procurement'), and changes in governance (new public-private partnership arrangements) will likely change urban public contracting in smart cities. He further explains the possible long-term consequences of the transformation in the urban functioning (i.e., becoming 'smart cities') in the categories of contracts, that is, urban public contracting in smart cities is leaning toward a multi-party system. More parties will be assembled both on the part of the contracting authorities and a wider range of contractors, complex contracts, i.e., more (functionally) global contracts, and long-term contracts, so that contractors' responsibility will extend beyond the completion of the infrastructure project to include its overall management in a given period of time.

The chapter by Folliot-Lalliot and McKeen explores some of the innovative procurement techniques that have been adopted in cities that are actively promoting smart development in the US and EU. In particular, they underline the special clauses, concerning data collection, data release policy, data protection, and dissemination in contracts for smart cities, which in the case of the City of Philadelphia, US, have resulted in the promotion of FastFWD, an innovative public procurement concept. Under FastFWD, the City gathers data across departments on a given problem and then will, where, possible, describe that problem in a manner suited to creative solutions ("problembased procurement methods and practices"). Once the need is identified, a multi-phase process follows, with an initial request for solutions for the identified need. This effort has attracted new companies and small businesses, with innovative ideas.

In the end, the procurement of 'innovative' products and services for the development of smart cities is a "key component in the creation and management of smart cities, and effective city governance structures influence its success".(6) The discussion presented in the above-mentioned chapters on

(6) See, e.g., N. Vergoulias, "Smart cities: is cutting-edge technology the method to achieving global sustainable goals?", in J. Envtl. L. \& Litig., 2017, 32, p. 272. 
smart cities is an example of how the procurement of innovative products, services and works, e.g., procurement of new technology collaborations for traffic congestion, and crime prevention in local communities in the US, calls for new practices in public procurement such as the development of smart public-private collaboration.(7)

Other equally important approaches are laid down in the EU Directive on Public Procurement. In fact, Recital 47 of the Directive is very clear in encouraging public authorities to use public procurement to spur innovation; it states in part:

"Buying innovative products, works and services plays a key role in improving the efficiency and quality of public services while addressing major societal challenges. It contributes to achieving best value for public money as well as wider economic, environmental and societal benefits in terms of generating new ideas, translating them into innovative products and services and thus promoting sustainable economic growth".(8)

In addition to the different approaches to innovation, i.e., pre-commercial procurement, the new Directives promote other models such as the use of public procurement for innovation (PPI) and innovation partnerships in helping Member States to ensure the promotion of "sustainable high-quality public services in Europe." Through the EU's public procurement of innovation, a procuring entity can act as the "launch customer or early adopter" for products and services that either are not available on the market, or have yet to reach a significant market share.(9) Some of the successful PPI projects are discussed in the chapter by Cavallo Perin and co-editor Racca. Interestingly, their chapter argues that central purchasing bodies had already experienced challenges in promoting innovative forms of cross-border administrative cooperation, according to European and national principles, even before the implementation of the 2014 Directive. In this regard, among the most advanced and innovative joint procurement experiences, the "Healthy Ageing Public Procurement of Innovations" (HAPPI) project(10) provided one of the first joint cross-border procurements to buy innovative solutions to promote healthy ageing. This experience stands out(11) for having combined product innovation ("what

(7) See L. Folliot-Lalliot and P. McKeen, "Procurement and smart cities: exploring examples on both sides of the Atlantic", Chapter 7 in this book.

(8) Recital no. 47, Dir. 2014/24/EU.

(9) M. BLAY, "The Strategic Use of Public Procurement in Support of Innovation", EPPPLR, 2014, 9 , pp. 3-11.

(10) BBG and SKI, Feasibility study concerning the actual implementation of a joint cross-border procurement procedure by public buyers from different Member States, 2017, pp. 33 et seq.

(11) As recently recognized by the EU Commission, Communication from the Commission to the European Parliament, the Council, the European Economic and Social Committee and the Committee of the Regions, "Making public procurement work in and for Europe", Strasbourg, COM (2017) 572 final, October 2017. 
to buy") in order to share the risks connected to the purchase of innovative solutions in the field of active ageing with a significant innovation of the procurement process, jointly designed and conducted by Central Purchasing Bodies (CPBs) (partners in the project) of different Member States ('how to buy'). The choice was to establish a European Purchasing Group which delegated the intermediary functions to the French CPB for the conclusion of a closed framework agreement with one economic operator, in accordance with EU and French law, with a combined effort of harmonization.

From the same perspective, Valcarcel shows how PPI can trigger the promotion of aggregation in public procurement among EU Member States. Citing various examples such as the project on the "Distributed European Community Individual Patient Healthcare Electronic Record" (DECIPHER) and the "Public Administration Procurement Innovation to Reach Ultimate Sustainability" (PAPIRUS), she highlights the role of collaborative and joint cross border procurement for buying innovative solutions. In the DECIPHER project, several EU Member States (i.e., Spain, Italy, United Kingdom and Finland) formed a consortium in conjunction with technology suppliers to define the technological solutions in health sectors which promote the use of mobile applications for ease of access of health data, which is an innovative product that has been developed during pre-commercial public procurement.

The chapter by Racolța and Dragos elaborates on the importance of innovation partnership in promoting research, development and innovation (RDI) in the EU by comparing it with another legal instrument, State aid for RDI. They discuss the relationship between these two instruments, including the opportunities and challenges for the use of each. Depending on the level of policy design, the specifics of legal regimes make the use of public procurement and State aid desirable in promoting RDI in different settings. Unlike State aid RDI, RDI under Article 31 of the EU Directive on innovation partnership allows the contracting authorities and the innovator-participants to agree on the subsequent purchase by the contracting authority of the resulting supplies, services or works that meet the authority's required performance levels within a maximum cost. In essence, the prospect of future procurement helps fuel research and development.

The procurement of innovative products is not a practice peculiar only to the European Union. It has become a common strategy among procuring entities across the globe. In the United States, for example, the promotion of innovative products is tied to a policy favoring advancement of small enterprises through the federal government's Small Business Innovation Research (SBIR) initiative. The chapter of Santerre-Funderburg and co-editor Yukins discusses how the U.S. SBIR program fosters innovation among small businesses by 
funding concepts at their earliest stages and then granting a procurement preference as those concepts are commercialized. Notably, the U.S. SBIR strategy is in many ways the forerunner to the European initiative on "innovation partnerships"; Christophe Kronke's piece discusses the goals and contours of that initiative in the European Union while Ponzio's chapter highlights the criticalities among PCP and PPI as addressed in the innovation partnership model, possibly taking advantage of knowing in advance the criticalities of the U.S. experience in SBIR.

Asian countries have also encouraged the procurement of innovative products through the promotion of the use of high-level technology (HLT). The Asian Development Bank (ADB) has already launched the "High-Level Technology Fund" with an objective of assisting ADB's developing member countries to adopt high-level technology and innovative solutions through the acquisition of equipment and goods that employ HLT, construction or civil works based on specifications that require contractors to meet enhanced performance standards and/or employ HLT in the construction process, materials and other inputs; and the hiring of consultants with specific knowledge and expertise in the use of HLT.(12) As of December 2018, the ADB High Technology Fund had financed thirteen (13) projects for the acquisition of HLT projects such as implementing innovative approaches for water governance in Mongolia which promotes the acquisition of HLT technology on groundwater quality and quantity monitoring systems. Molino's chapter summarizes the other innovations in public procurement that the ADB is currently promoting in its Member States.

Irrespective of approach, a successful purchase for innovation requires an intensive market consultation, an argument posited by Lopez in his paper, "Preliminary Market Consultation in Innovation Procurement: a principled approach and incentives for anticompetitive behaviours" and supported by Gimeno Feliu in his extensive analysis of the EU's procurement reform as a strategy for the development of innovation policy; more particularly, his arguments on leveraging the purchasing power by the EU public procurers in acquiring innovative products and services in order to improve the efficiency and quality of public services with a view to promoting the Europe 2020 plan for smart, sustainable and inclusive growth.

(12) Asian Development Bank, "High-Level Technology Guidance Note on Procurement", June 2018. 


\subsection{Innovation in Procurement}

A second meaning of 'innovation in procurement' is encouraging innovative suppliers in the procurement process $(13)$ - to encourage those that will provide innovative solutions, rather than simply low price. This tension between low price and best value divides modern procurement, for while most systems presumptively favor awards based on low price, as they are simpler and pose less corruption risk, more advanced procurement systems typically strive towards more subjective best-value awards and broader value-based approaches which embrace innovation and yet also entail further risks and require special evaluating capacities.

What is interesting about this approach is that while most of the innovative solutions in public procurement address the issues from the demand side (collaborative procurement, for example, encourages the use of collective purchasing power among public authorities, or the use of e-procurement to leverage technology for a more efficient administrative procedure), the move to encourage innovation through procurement is shifting the so-called 'burden' to innovate to the supply side.(14)

One leading example is the use of Building Information Modelling (BIM) for the procurement of construction or work services, a topic that is extensively discussed in the chapter of Di Guida and co-editor Racca. Under the traditional approach to public procurement, collaboration between and among contractors or economic operators, unless they will participate as a single offeror by submitting a single bid or proposal in a particular project as a jointventure or consortium, is often highly regulated, if not totally prohibited. The reason for this is that collaboration among them poses a high risk for potential bid-rigging or may even trigger the possibility of creating a harmful collusion or worse corruption in the market, which would contravene the overarching principle of open competition in public procurement.(15) BIM, on the other hand, encourages collaboration even among contractors through the establishment of what is known as a 'framework alliance' or a contract between

(13) See S. Kelman, "Meet the Contracting Folks Who are Encouraging New IT Vendors", Public Spend Forum, March 2018.

(14) G.L. Albano, "Demand aggregation and collusion prevention in public procurement", in Integrity and Efficiency in Sustainable Public Contracts. Balancing Corruption Concerns in Public Procurement Internationally (G.M. RACCA and C.R. Yukins eds), Brussels, Bruylant, 2014, p. 155; G.L. Albano and C. Nicholas, The Law and Economics of Framework Agreements, Cambridge, CUP, 2016.

(15) A. SÁnchez Graells, "Prevention and deterrence of bid rigging: a look from the new EU directive on public procurement", in Integrity and Efficiency in Sustainable Public Contracts. Balancing Corruption Concerns in Public Procurement Internationally, op. cit., p. 171; A. LóPEZ MiÑo and P. VALCARCEL FERNANDEZ, "Contracting authorities' inability to fight bid rigging in public procurement: reasons and remedies", in Integrity and Efficiency in Sustainable Public Contracts. Balancing Corruption Concerns in Public Procurement Internationally, op. cit., p. 199. 
"one or more suppliers in order to establish the terms governing the project contracts that are awarded over an agreed period",(16) albeit, not necessarily creating a single proposal or bid among parties therein. While a framework agreement is used in times when the contracting officer has an open-ended for the products or services, subject to the framework agreement, the framework alliance is an agreement between and among suppliers or contractors within a supply chain, though they may not necessarily be within the same line of industry. For example, in the supply chain for building construction, an alliance may be formed among a group of architects for the design, another group of engineers for the building phase, and a new group of economic operators for future construction maintenance. An Alliance Manager, supported by the new technologies (smart contracts, blockchain), should assure the right incentives for all the alliance partners to further the common goal of a prompt and efficient execution, overcoming the opportunistic behavior of suppliers after the award.

Another important approach under this category is the innovation in public procurement under the Egyptian public private partnership (PPP) legislation. While establishing a public private partnership is, more often than not, exempted from the coverage of public procurement legislation,(17) Judge Ismail explains that the Egyptian legislation governing PPPs stipulates that investor selection is subject to the principles of publicity, transparency, free competition, equal opportunity, and equality. Although there is no special administrative organ in Egypt that is concerned with State procurement, the PPP legislation stipulates that a special pre-qualification committee shall be established by an administrative decree from the concerned authority, and to maintain fair competition and equality the administrative authority may use a 'dialogue process' in selecting the best private partner.

Innovation under this perspective is not or should not be limited to the ability of the procuring entities to acquire the 'best-value' products or services from innovative suppliers. Procuring entities must also be able to do it in the most efficient way, that is, at the time when the products or services are actually needed. Otherwise, no matter how innovative the products or services that are delivered by so-called innovative suppliers, if the products or services arrive after the fact, then their 'use value' diminishes in time. This may be one

(16) G.M. Di GuIDA and G.M. RACCA, "From Works Contracts to Collaborative Contracts: The Challenges of Legal BIM", Chapter 8 in this book.

(17) See World Bank Group, "What are public private partnership?", February 2018: "PPPs typically do not include service contracts or turnkey construction contracts, which are categorized as public procurement projects, or the privatization of utilities where there is a limited ongoing role for the public sector." 
of the reasons why the concept of 'amazon.gov' even emerges, which is a topic covered by the chapter of McKeen.

McKeen shows us a picture of a future-scenario that is already unfolding: an official ordering goods to meet public requirements much as a private person would order home supplies from one of the biggest online markets, such as Amazon. The failure of a procurement system - even one from a highly-advanced economy such as the US - to address public requirements efficiently and well has triggered government support (in both Congress and the agencies) for a platform for public procurement that is more expedient and more market-responsive at a presumably reasonable price, by attempting to simulate, if not necessarily adopt, the procurement processes in the "current commercial e-portal market" through the use of e-portals on a government wide basis. Whether this will in fact encourage innovative suppliers to participate in public procurement is yet to be seen. Or to pose a simple question, can a more liberalized model of public procurement promote more innovation? The risks of non-transparent algorithms and discrimination in commercial platforms remain and provide an extraordinary incentive for promoting effective procurement systems using more traditional means.

\subsection{Innovation in the Procurement Process}

A third meaning is innovation in the procurement process itself as new methods and approaches for the procurement process. This introductory chapter, and the accompanying chapters by Locatelli, Simovart and Borodina, Pignatti, Ponzio, and McKeen, address these new approaches.

Locatelli discusses digitization, the use of self-declaration via a standard form European Single Procurement Document (ESPD), joint cross-border procurement (JCBPP) and cooperative procurement via institutional bodies (e.g. CPBs) as the main innovations under Directive 2014/24/EU on public procurement. He argues for the need for the EU Member States to go beyond the compulsory requirements of the Directives by combining full digitization of the procurement process from planning to archiving ('end-to-end e-procurement'), and stresses the possibility of cooperation between large buyers in areas of mutual interest or between buyers not necessarily located in bordering areas ('joint cross-border procurement'). Although public procurement remains highly regulated, he explains that the novel approaches under the new Directives encourage the Member States to establish public procurement systems which may overcome market fragmentation and generate efficiencies and savings, and which can contribute to economic growth. He argues, importantly, that the Directives mark a pathway to improved procurement systems in the Member States. 
Since the transition to 'digitized' procurement process is becoming inevitable in EU Member States, i.e., the new directives call for the gradual yet mandatory transition of the initial phases in the procurement cycle to e-procurement, then the development of innovative procurement tools that will enhance efficiency in public procurement without compromising other procurement principles such as integrity, transparency, and competition is now a necessity. That objective can best be addressed by expanding the procurement networks among contracting officials across borders in order to share best practices that may be adopted or modified to meet the requirements not only of the end-users or the public in general, but, more importantly, to ensure compliance with the evolving regulations in procurement processes.

Simovart and Borodina give us a good example of the implementation of digitization under Directive 2014/24/EU using the Estonian e-Procurement Model (e-PR). They attribute the success of the e-PR (i.e., increasing the share of electronic procurement to $92 \%$ in 2016 and facilitating a smooth transfer to $100 \%$ e-procurement soon) to the comprehensive nature of the whole electronic procurement environment, that is, e-PR not only supports full electronic award procedures (i.e., from pre-award phase to the awards of the contracts), it also contains an electronic register of complaints (i.e., registration of complaints is limited to the lists of the complaints submitted to the Complaints Board and the decisions made; submission of complaints is not yet included) as well as access to a user help and information portal (e.g., legal regulations on both EU and the national level, references to Court cases and summaries of case law of both the CJEU and Estonian Supreme Court, research conducted on the request or by the Ministry of Finance, etc.). Pignatti, on the other hand, elaborates on various electronic tools that may be used within the entire procurement cycle, which Ponzio supports by expounding on the best practices in innovative procurement across Eastern Europe. From another perspective Romeo, in her chapter on "Autonomy and Innovation in Italian Regional Procurement: The Sicilian Model" analyzes whether the European principles of opening the market and free competition can actually prevent various forms of barriers and/or possible discrimination in access to regional public procurement markets.

Despite the various forms of innovation in public procurement, there is still a challenge in how other jurisdictions, most particularly those in developing countries and even some countries with emerging economies, might catch up with the innovations in public procurement among advanced economies such as the U.S. and the EU Member States. In fact, while 'best value' or Most Economically Advantageous Tender (MEAT) procurement is already a staple in advanced economies; that is, it is rare (in the U.S. federal market) 
to see a complex procurement procedure that is not based on a "best-value" trade-off between quality and price, it is still a principle sometimes resisted among procurement specialists in developing countries where procurement is primarily based on 'low-priced' awards.

The evolution of the MEAT to a value-based approach in specific sectors seems to be the future challenge for innovation.(18) The outcome-based healthcare model, for example, should provide a patient-centric approach with outcome measurements of the improvement both to the quality of care for patients and to the system in terms of sustainability (circular economy principles) and efficiency, to assure the long-term strength of healthcare systems.

The good news is that international organizations such as the Organization for Economic Cooperation and Development (OECD) have international tools (e.g., the Methodology for Assessing Procuring Systems - MAPS) that are used to promote quality assurance, among other goals. MAPS was originally intended to protect the funds from OECD donor-countries that are being spent in developing countries from potential risks caused by those countries' procurement systems; MAPS has, in fact, evolved into a quality-assurance tool for a more "innovative" procurement system in non-OECD countries. For a complete appreciation of the OECD MAPS, please refer to the chapter of Magina and Diesing on innovation in the evaluation of public procurement systems.

In our introduction here, we have decided to focus on innovative procurement that crosses borders not only because it poses some of the toughest challenges in modern procurement, but also because it so successfully captures the other forms of innovation: cross-border procurement, while very innovative, also makes it easier for agencies to purchase innovative solutions emerging around the world, and nurtures innovative suppliers.

\section{Innovation Through Cross-Border Procurement: Key Constraints}

At present, probably the most ambitious innovation in procurement is 'joint procurement', either inside a country (overcoming the traditional coincidence

(18) See EURIPHI project (European wide Innovation Procurement in Health and Care) Consortium (involving $14 \mathrm{PPOs}$, of which 10 have a regional or national remit and service providers from 6 countries who, together, procure for more than 200 care service providers), developing a Value-Based Procurement of innovative solutions to enable the cross-border transformation of health and social care delivery. 
of the procuring entity that buys for itself) and the even more challenging cross-border procurement, which typically involves cross-border cooperation (often cooperation between public agencies, or central purchasing bodies) from different countries.

This type of cross-border cooperation is emerging around the world; in the United States, it is commonly referred to as 'cooperative purchasing',(19) while in Europe it is called 'joint procurement'. In his chapter on cooperative purchasing in the United States, Kaufman discusses some of the U.S. strategies for cooperative purchasing among States - strategies that present, in many ways, illustrative examples of the same legal and management issues that dog joint purchasing in the European Union, described by Roberto Cavallo Perin with co-editor Gabriella Racca, Ivo Locatelli and Particia Valcarcel in their respective chapters.

The main focus here is on cross-border procurement, which presents ancient problems but offers remarkable promise for the future.

The 2014 Procurement Directive not only explicitly allows contracting authorities to cooperate in joint cross-border procurement but forbids Member States to prohibit such possibility. It explicitly states that "[a] Member State shall not prohibit its contracting authorities from using centralized purchasing activities offered by central purchasing bodies located in another Member State", and indicates that national law in conflict with these provisions would be in breach of the Directive. It is clarified that cross-border procurement should not be used for the purpose of avoiding the application of national mandatory public law provisions. As with any European provision the Directive language endorses, cross border-procurement should not be applied with elusive, distorting illegal purposes. The same Directive recalls the legal and practical difficulties in purchasing from contracting authorities located in other Member States or jointly awarding public contracts; yet, it also recalls that the aforementioned cooperation was already possible according to common principles of cooperation.

The initial cross-border procurement supported by EU pilot projects saw the evolution from benchmarking to directed coordination, and eventually to the definition of common technical specifications related to separate procedures, to award procedures delegated to other contracting authorities, and purchases of goods and services from delegated central purchasing bodies of other Member States or more recently through the establishment of European

(19) See, e.g., F. Trowbridge Vom Baur, "A Personal History of The Model Procurement Code", Pub. Cont. L.J., 149, 1996, 168; id., "Early Days of Government Contract Practice", Public Contract L.J., 1989, 18, pp. 446-459. 
joint subjects established under national or Union Law.(20) Also European Groupings of Territorial Cooperation (EGTCs) might fit the cooperation among CBPs from different countries for the purpose of establishing cooperation for joint cross-border procurement.

In the U.S., some examples of joint purchasing: cooperative purchasing, as made available to State, local and tribal governments by the U.S. federal government's primary centralized purchasing agency, the General Services Administration (GSA), under GSA's Multiple Award Schedules (MAS) contracts (the largest framework agreements in the U.S. federal government, worth tens of billions of dollars per year); and, cooperative purchasing made available to a broad variety of State and local agencies under the National Association of State Procurement Officials (NASPO) ValuePoint contracts (which are described in much more detail in Justin Kaufman's accompanying piece).

We should stress that we are drawing on selective examples here. Not all GSA frameworks agreements, for example, are available for cooperative purchasing; our focus here is only on the information technology agreements, which can be used by State and local purchasers in the United States. For an effective comparison, we will similarly focus on the information technology contract sponsored by NASPO-ValuePoint, the multi-billion-dollar contract which is run by the State of Minnesota on behalf of the other NASPO-ValuePoint members.

To gain a better sense of joint procurement's future trajectory, the focus is on the institutional constraints that do so much to shape joint procurement. Those constraints also relate back to the first two types of innovation in procurement - though cross-border procurement is itself innovative, the constraints that slow this strategy make it more difficult to purchase innovative technology across borders, and to foster innovation among prospective contractors.

Cross-border procurement is inherently clumsy, because it requires different public agencies to reconcile and apply their sometimes radically different rules. While recent moves towards harmonization make it easier to reconcile different systems' regulatory regimes,(21) stark differences remain, in part because those differences reflect divergent approaches to the social and political issues that often inform procurement law. At the end of the day, therefore, joint or cooperative purchasing (we will use the terms interchangeably) demands compromises between legal regimes.

(20) In particular, art. 39, Dir. 24/2014/EU, includes "European Groupings of territorial cooperation under Regulation (EC) No. 1082/2006 of the European Parliament and of the Council" among those joint entities which may be set up by "contracting authorities from different Member States" to carry out joint cross-border procurement.

(21) See, e.g., United Nations Commission on International Trade Law (UNCITRAL), "Model Law on Public Procurement", 2011; WTO, "Agreement on Government Procurement”, 2012. 
Despite the awkwardness inherent in cooperative purchasing, it does offer real promise as an innovative way forward.

Cross-border purchasing makes it possible to consolidate public purchasing demand in not one but many jurisdictions, and so makes it easier for public agencies to deliver higher quality, lower-priced goods and services to their constituent populations.

In the case of the European Union, cross-border procurement could become a strategic tool for strengthening the European single market, promoting capacity building among contracting authorities, and advancing social and environmental goals.(22)

The different perspectives that inform cooperative purchasing in the United States will become evident and of great interest especially as they show that the rules and principles of the European Directives on procurement deeply affect all levels of European procurement, from the national level to the smallest municipalities. This difference, as outlined already in our previous book, shows how from this perspective the European Union goes much further in fostering cross-border procurement than the U.S. federal government, with all the subsequent consequences.

The combined purchasing power and the possible goals of industrial policy of Member States, focused on specific sectors or in a much limited scale among public central purchasing bodies or even municipalities or regions from the same or different Member States, can be advanced through joint procurement.

Joint procurement, especially in the European context, does not necessarily mean huge contracts but can promote specific strategies related to each relevant market. Such strategies may call for the division of requirements into smaller lots in order to encourage participation and the growth of SMEs, depending on how many economic operators are involved in any relevant procurement market.

Cross-border purchasing also might allow public agencies to leapfrog corruption and, from this perspective, there is a continuity with the previous book in this series(23) that focused on integrity and efficiency issues that, in this new and wider perspective, are always taken into account. A public buyer in a corrupt country, isolated in a sea of corruption, could in principle purchase from, through cross-border procurement instruments, a "clean" centralized

(22) R. Cavallo Perin and G.M. Racca, "European Joint Cross-border Procurement and Innovation", Chapter 3 in this book.

(23) G.M. RACCA and C.R. YukINs (eds), Integrity and Efficiency in Sustainable Public Contracts. Balancing Corruption Concerns in Public Procurement Internationally, coll. Droit administratif/Administrative Law Collection (J.-B. Auby dir.), Brussels, Bruylant, 2014. See also G.M. RACCA, R. CAVALLo Perin and G.L. Albano, "Public Contracts and International Public Policy Against Corruption", in Transnational law of Public Contracts (M. AUDIT and S.W. ScHILl eds), Brussels, Bruylant, 2016, p. 845. 
purchasing agency in another jurisdiction, which would thus be in a stroke both bypassing and disabling a corrupt procurement system. Similarly, joint purchasing might permit procuring entities to face down cartels or unreasonable fragmentations of the market in specific sectors.

Finally, and most practically, cross-border procurement allows public purchasers to diversify their supply chains, which sharply reduces the risk that those supply chains will collapse - or concomitantly, that prices will balloon out of control - when local emergencies or natural disasters strike, as inevitably they do.

The promise of cross-border procurement must, of course, be weighed against its perils. Joint procurement faces severe constraints, some of which are detailed below. Those constraints impose practical limitations on crossborder procurement, and - equally importantly, for our purposes here - suggest how lawyers and regulators should think critically about cross-border procurement, as it expands in importance.

\subsection{First Constraint: A Friendly Environment}

The cross-border compromises inherent to joint procurement in turn present the first institutional constraint: only cooperative public bodies can embark on joint procurement together, which probably means that only friendly governments or other contracting entities, not adversaries, can engage in joint procurement.

Reciprocal defense procurement agreements between the United States and its allies(24) probably mark the outer boundary of this practical constraint: they demand technical cooperation in the purchase of defense materiel and supplies, to enhance interoperability in defense operations, which means as a practical matter that only allies, not enemies, can join these agreements. For many of the same reasons, Schoeni shows how it is probably no accident that the two most prominent examples, internationally, of cross-border procurement - in the European Union, and between States in the United States - arose in the context of stable systems, already politically and economically integrated.

As noted, one example for integration might be the European Grouping of Territorial Cooperation (EGTC). Interestingly, no similar integration is prevalent among U.S. States. EU Member States are encouraged to develop various forms of administrative cooperation towards an integrated system of public administrations for the enhancement of EU social cohesion. In fact, most EGTC structures remain within limited geographical areas ('non-hostile

(24) See U.S. Department of Defense, "Reciprocal Defense Procurement and Acquisition Policy Memoranda of Understanding", October 2017.

BRUYLANT 
environments') and particular sectors with 'common economic interests' that might also entail joint procurement activities.(25)

Conversely, this constraint - cooperative procurement works far better among friends - means that it probably will be much more difficult to use cross-border procurement in hostile environments, such as in post-conflict circumstances or in countries experiencing hyper-corruption. Thus, for example, it would be very difficult for a schoolteacher in a war zone to purchase through a centralized purchasing agency in another, safer country; although the purchase itself might be done across the Internet, perhaps even on a mobile phone, the practical, legal and financial obstacles might well make the purchase unworkable or very difficult.

To overcome these challenges and fulfill the promise of cross-border purchasing, much more careful attention will need to be paid to 'ruggedizing' joint procurement if it is to be extended to high-risk environments. To serve as a useful tool in hostile environments, cross-border purchasing should be made as simple as possible, and delivery and payment should be straightforward and, where necessary, secured through traditional means of assuring performance, such as stand-by letters of credit.

In considering these efforts to make cross-border purchasing work in hostile environments, purchasing authorities may wish to consider the electronic commerce model suggested by Section 846 of the U.S. National Defense Authorization Act for fiscal year 2018.(26) U.S. agencies will be pilot-testing commercial electronic commerce platforms for purchases under the lowest threshold (roughly $\$ 10,000$, and potentially much higher). This new approach - dubbed 'amazon.gov' by some - means that public purchasers will be able to buy directly from commercial marketplaces, bypassing traditional public procurement requirements for publication, qualification and competition. Despite misgivings by some, this new highly commercial approach might make it easier for government users in post-conflict or highly corrupt environments to purchase across borders. As already recalled the transparency issues with this approach have yet to be taken fully into account.

\subsection{Second Constraint: The Context}

The second, related constraint stems from the broader political, legal and administrative context in which public agencies undertake joint procurement - and while it is related to the first, this constraint highlights differences, not similarities.

(25) R. Cavallo Perin and G.M. Racca, "European Joint Cross-border Procurement and Innovation", Chapter 3 in this book.

(26) See generally, U.S. General Services Administration, Procurement Through Commerical E-Commerce Portals Phase II Report: Market Research \& Consultation, April 2019. 
Joint procurement in the European Union receives strong support from Brussels because (it is hoped) that cross-border cooperation in procurement will also help to develop internal market and to integrate the European States - the ultimate goal of EU policy.(27)

In the United States, in contrast, cooperative purchasing has grown as a means of reducing cost and improving procurement outcomes; there is almost no overarching goal of integrating the U.S. economy through cooperative purchasing.

These partially differing policy goals lead to different legal outcomes. While our focus here is on institutional issues, the rules reveal a great deal - like the wind's ripples on a sand dune, the institutional forces seem to leave tracing marks on the legal rules that govern cooperative purchasing.

Take, for example, the legal issue of which procuring entity will bear the risk of transparency and competition - which entity, in other words, is ultimately responsible for ensuring that cross-border awards are done in a fair, competitive and transparent manner. How that risk is allocated and addressed is an important measure of the rules governing a system of joint procurement.

The two U.S. models under study here (the GSA schedules and the NASPO ValuePoint vehicle) leave that risk largely with the customer agency. The GSA schedule contract says the risks of loss or damage to the supplies under the GSA contract typically will remain with the supplier until delivery,(28) while the ValuePoint contract shifts the risk of loss to the local customer agency.

While historically the NASPO ValuePoint contract might have read a local requirement into the contractual framework, the NASPO ValuePoint master agreement (the master framework agreement between a lead State and its vendors) was redrawn recently. Previously, the master price agreement provided that if a customer agency's laws required a specific provision - a provision mandating competition, for example - that provision would be read into the framework contract between a vendor and the purchasing agency - and the framework contract would take precedence.

That strong precedence for special local requirements has disappeared from the ValuePoint contracting system. The current master agreement now provides merely that the local jurisdiction's direct contract with the contractor (the 'Participating Addendum') is to be interpreted consistently with local law; the revised contractual structure, however, gives no effect to local requirements not called out in the Participating Addendum. In practice, this means that if

(27) EU Comm., "Recommendation on the professionalisation of public procurement: Building an architecture for the professionalisation of public procurement", C(2017) 6654 final, October 2017.

(28) See, e.g., General Services Administration Federal Supply Service Authorized Federal Supply Schedule Price List, Contract No. GS-00F-0049M Ordering Period: 3/29/02 - 8/23/19, 37. 
the implementing contract is silent, local requirements - such as competition or transparency requirements - can be bypassed completely. What this means, in practice, is that the buying agency bears almost all risk of compliance.

The GSA schedule contracts shift those burdens even more starkly to the State and local governments that use the GSA framework agreements under cooperative purchasing. This may be because cooperative purchasing was, to some extent, forced on GSA by Congress: GSA offers cooperative purchasing for only certain frameworks (such as information technology, Schedule 70), and even that arrangement had to be specially mandated by Congress.

The standard GSA schedule terms, which define certain obligations that are shaped by federal law and policy - how payment will be effected, for example may be amended to accommodate non-federal customers (the payment clause, for example, can be modified to accommodate a local buyer standing in the shoes of a federal agency). Beyond that, though, the GSA acquisition regulations cut the local or State framework agreement free from the master framework agreements (the GSA MAS contracts): the regulations provide that a contract between a vendor and a buying agency forms a new contract, "which incorporates the terms and conditions of the Schedule contract" but under which the "U.S. Government shall not be liable", whether for performance or nonperformance.(29) The GSA contracts, in short, do not resolve how local mandatory requirements should be addressed when local governments use these federal contracts.

The terms of the GSA schedule agreements, when applied to cooperative purchasing by State and local governments, thus reflect the federal government's very limited interest in integrating procurement regimes across the United States: the federal government is willing to allow State and local governments to economize by using (replicating, really) the GSA schedule contracts, but the federal government makes essentially no effort to use the framework agreements as an integrative tool. Conversely, in fact, the federal government's 'hand's-off' approach shifts substantial transaction costs to customer agencies at the State and local levels (because they must fill all the contractual gaps left by the federal government), and (by neutralizing the robust federal framework agreements) can increase risks for using agencies.

The European Union's main procurement directive suggests another way forward, one that reflects the European Union's abiding interest in economic integration, and in joint procurement as a means of encouraging innovation. The European directive's recital 71 states, in relevant part (with emphases added):

(29) GSAR 552.238-79, 48 CFR $§ 552.238-79$, Use of Federal Supply Schedule Contracts by NonFederal Entities. 
"Where several contracting authorities are jointly conducting a procurement procedure, they should be jointly responsible for fulfilling their obligations under this Directive. However, where only parts of the procurement procedure are jointly conducted by the contracting authorities, joint responsibility should apply only to those parts of the procedure that have been carried out together. Each contracting authority should be solely responsible in respect of procedures or parts of procedures it conducts on its own, such as the awarding of a contract, the conclusion of a framework agreement, the operation of a dynamic purchasing system, the reopening of competition under a framework agreement or the determination of which of the economic operator party to a framework agreement shall perform a given task".

From a U.S. perspective, the Directive's allocation of responsibilities in joint procurement seems commonsensical: by allocating responsibility among the parties based on which party controls a particular step in the procedure, the Directive is following the same principle of 'cheapest cost-avoider' which is a staple of U.S. risk-allocation approaches. More markedly, the Directive's allocation of responsibilities does not follow the approaches of the ValuePoint and GSA arrangements discussed above, which aggressively shift many more burdens to the State and local purchasing agencies. In Europe, by the same logic, national mandatory requirements should be applied in European joint cross-border procurement too.

Perhaps most importantly, though, the Directive's recitals reflect an understanding in the European Union that remedying the allocation of risks and obligations between parties to a joint procurement should facilitate that crossborder procurement. Recital 73 notes that joint procurement "by contracting authorities from different Member States" often encounters "legal difficulties concerning conflicts of national laws", and as a result "contracting authorities are still facing considerable legal and practical difficulties in purchasing from central purchasing bodies in other Member States or jointly awarding public contracts". To ease these problems, the recitals suggest that in "order to allow contracting authorities to derive maximum benefit from the potential of the internal market in terms of economies of scale and risk-benefit sharing", new "rules on cross-border joint procurement should be established in order to facilitate cooperation between contracting authorities [...] by creating crossborder business opportunities for suppliers and service providers".

The text of the Directive's Article 39 goes a step further, and suggests a burden-allocation that could radically reshape the way that joint procurement is done - a reallocation apparently driven, again, by the institutional support in Europe for joint cross-border procurement and administrative cross-border cooperation. 
The Directive's Article 39 shifts the center of gravity towards the selling agency (the centralized purchasing agency which coordinates the joint procurement), and says that the national laws of that centralized purchasing agency (including, presumably, national laws regarding competition and transparency) will govern important steps through joint procurement:

"The provision of centralised purchasing activities by a central purchasing body located in another Member State shall be conducted in accordance with the national provisions of the Member State where the central purchasing body is located.

The national provisions of the Member State where the central purchasing body is located shall also apply to the following:

(1) the award of a contract under a dynamic purchasing system;

(2) the conduct of a reopening of competition under a framework agreement;

(3) the determination pursuant to points (a) or (b) of Article 33(4) of which of the economic operators, party to the framework agreement, shall perform a given task".(30)

Applying these European rules to the U.S. structures apparently would mean, for example, that an order awarded under a ValuePoint contract would be governed by the sponsoring State's competition and transparency rules. Similarly, were this rule to apply in the United States, orders by State or local governments made through cooperative purchasing under the GSA schedules might be covered by strict federal competition and transparency rules, and could be subject to the federal government's protective terms and conditions. The rule proposed by the Directive, in other words, could lend cooperative purchasing in the United States very important legal structure and protections.

Rather than leaving important elements of the contracting process undefined - as ValuePoint and the GSA schedules do - the European rule, born of integration, could integrate joint cross-border procurement into mature, protective regulatory regimes. This could lead to effective harmonization of national implementations, through administrative cooperation and joint procurement experiences.

There could be practical effects, too, if the European rule were applied to U.S. forms of cooperative purchasing. The sponsoring agencies' mature procurement systems - GSA's relatively sophisticated means of ensuring competition and transparency for schedule orders, for example - could be extended, in practical terms, to orders by customer State or local governments. In the ValuePoint system, if the orders were subject to stricter and enforceable rules of competition and transparency, the sponsoring agencies would

(30) Dir. 24/2014/EU, Art. 39(3).

BRUYLANT 
have incentives to develop transparent and competitive ordering systems that customer agencies could use; in this way, ValuePoint orders by State or local governments could no longer be made 'invisibly'. By making the sponsoring agency's own rules applicable to cooperative purchasing, the European rule could, in effect, nurture contracting processes (transparency and competitive ordering, for example) which took advantage of the sponsoring agencies' mature contracting systems.

Those practical changes of course would need to take into account the third constraint we will discuss here: the nature of the sponsoring centralized purchasing agency itself. In assessing whether and how joint procurement should be regulated and directed, policymakers must be frankly conscious of the unique perspectives - and conflicts of interest - that the centralized purchasing agencies may bring to joint procurement.

The European pioneering experiences on joint procurement might take advantage of all the risks and challenges faced in the U.S. and promote the European goals through similar tools applying EU social goals.

\subsection{Third Constraint: The Centralized Procurement Agencies}

The third constraint relates to who is coordinating the joint purchasing (or joint procurement): the centralized purchasing bodies which carry their own sets of problems and pathologies. The using agencies which rely on joint procurement typically are as disparate as their missions, from health to defense. In contrast, the selling agencies - the centralized purchasing agencies (bodies) that offer cross-border procurement - tend to be focused on common business imperatives of increasing sales, revenues and (sometimes) profits, in the U.S. experience. Again, in this perspective the European experience is still at the very early stages except for some more advanced experiences in national joint procurement. The strategic use of public procurement for industrial policy objectives, to drive sustainability and innovation, is highlighted in the text below as the next challenge.

The centralized purchasing agencies' goals are not, of themselves, objectionable; they do suggest, though, that prudent regulation may be needed in crossborder procurement, because the central actors themselves may be distracted by institutional imperatives that are not resolved by the normal dynamics of a procurement market.

The two examples from the United States may help illuminate these points. The first is GSA, the centralized purchasing agency at the heart of the federal government which oversees tens of billions of dollars in annual purchases. GSA's centralized purchasing function is sustained by user fees, not 
appropriations, an institutional imperative which shapes GSA's procurement strategies - including cooperative purchasing.

Because GSA has strong institutional imperatives to contain costs and risks, and because State and local governments across the United States present a geographically dispersed, fractured market outside GSA's normal core mission of serving federal agencies, GSA has every incentive to contain its exposure to cooperative purchasing. The contracting system used to implement GSA's cooperative purchasing reflects that approach: as was described above, while GSA allows State and local governments to use certain GSA schedule contracts through cooperative purchasing, GSA extends almost none of its normal legal protections or processes to those State and local government user agencies. GSA has, it seems, structured cooperative purchasing to minimize its own administrative costs and legal exposure.

The ValuePoint model offers its own lessons, informed by the unique posture of the State purchasing officers who shape the model. Their membership organization, the National Association of State Procurement Officials (NASPO) is, after all, the sponsor of the ValuePoint model, NASPO earns fees from the ValuePoint contracts, centralized State purchasing agencies run the master framework agreements, and State agencies typically may buy from those agreements only if the State purchasing officers give their permission. The NASPO ValuePoint structure thus presents a welter of potential conflicts of interest; we will focus here on only one, as illustration, which manifests in ValuePoint's heavy reliance on original equipment manufacturers (OEMs) rather than resellers.

Centralized purchasing agencies present a classic principal-agent conflict of interest problem in procurement: they are agent-intermediaries whose interests may diverge radically from those of user agencies. The centralized purchasing agencies that sponsor the ValuePoint master agreements are no different: while they have an interest in making goods and services available to customer agencies in other jurisdictions in order to spread administrative costs across more sales and enhance the agencies' collective negotiating leverage with vendors, the sponsoring centralized purchasing agencies have an acute interest in reducing costs and legal exposure.

That self-interest in the sponsoring agencies helps explain why the ValuePoint information technology contract, which is used for billions of dollars in annual purchases, is limited to 30 OEMs. (The counterpart GSA Schedule 70 information technology contract, in contrast, includes thousands of OEMS and resellers). The centralized purchasing agency implementing the ValuePoint contract has decided not to rely on resellers - typically smaller businesses which offer more diverse solutions, but which can present idiosyncratic 
performance risks - and instead to contract only with OEMs, which naturally limits competition and choice in the ValuePoint marketplace. The focus here is not on whether that trade-off makes sense, but rather on the fact that it $i s$ a trade-off - a conscious management decision driven by the centralized purchasing agency's own posture and institutional imperatives, which may not yield optimal results.

The U.S. experience on central purchasing bodies through either the GSA model (sanctioned by the U.S. federal government) or the ValuePoint model (sanctioned by the participating States) points up the fact that the European Union does not have a 'EU central purchasing body' comparable to the GSA, but the U.S. experience suggests the importance of cooperation to reduce administrative costs and to consolidate public purchasing powers though with the same perils in potential conflicts of law.

It is interesting to learn how U.S. federal procurement, with all its sophistication and efficiency, has not been a constraining model for most State and local procurements. The States generally maintain a separation from the federal government in terms of procurement means and goals. Aside from limited guidance for State and local procurements done with federal grants, there is no 'Federal Procurement Directive' to promote the opening of a 'U.S. procurement market', comparable to the EU Directives, which seek to open EU public procurement markets, with strategic goals underlying European procurement policy.

In fact, the European experience on joint cross-border procurement may be considered in an early stage when compared to the U.S. one, so that many of the issues are not yet manifested or have been solved through European principles or have been correctly addressed in the rules. In fact, most of the EU joint cross-border procurements were developed as pilot projects funded by EU funds. One may argue that the EU is trying to, so to speak, avoid the similar risks posed by the U.S. 'umbrella contracts', which is why it opts to learn from the pioneering experiences of cooperating EU Member States.

The actual aim is to encourage the 'horizontal cooperation agreements' of joint entities such as the ETCGs in order to take full advantage of a European single market for the benefit of the European citizens. Unlike the U.S., the EU's approach in promoting joint and cross border procurement through central purchasing bodies is not only to ensure cost-savings but also to promote other goals such as encouraging cross-border participation of SMEs, counteracting cartels, assuring integrity and efficiency, furthering environmental and other social goals, and developing circular economy tools. Interestingly, despite convergence, the EU's perspective on "Unity in Diversity" allows EU Member States to promote those 'other goals', which can be shared cross-border on a 
case by case basis and which could result in some of the same 'trade-off' issues that U.S. agencies are currently addressing.

\subsection{Fourth Constraint: Language Barriers and Limited Procurement Professionals}

Since cross-border procurement covers contracting authorities from different procurement entities in multiple States and local agencies, it calls for procurement professionals who are adept not only in their own procurement regulations and practices but also, potentially, in the regulations and practices of other procuring entities that use the cross-border procurement vehicle. As already discussed in the chapters of Kaufman, Cavallo Perin and Racca, crossborder procurement poses challenges not only in addressing significant issues arising from variations in their procurement regulations and practices, but more importantly in managing cooperative contracts. Cross-border procurement requires a balance between efficient delivery of products and services that offer best value for the government, and the need to ensure fair and open competition in a manner that is ethical and transparent. Procurement professionals must strike that balance while they continue to search for innovative ways of improving the acquisition process without violating the basic principles of fairness and competition.(31)

The 2017 European Commission report on cross-border trade in public procurement highlighted "unfamiliar legal context or formal requirements (e.g., contract, labor law, certificates to provide such as special permits necessary for offering services abroad etc.) leading to market entry barriers in awarding the country" and language barriers as two of the perceived obstacles to cross-border procurement by both the businesses (sell side) and the contracting authorities (buy side).(32) While a language barrier might not be an issue in cooperative purchasing among U.S. States, i.e., English is the common language irrespective of States and local agencies, it can be a big challenge among procurement professionals in EU Member States, since the EU has 24 official languages.(33) In fact, the EU small and medium enterprises (SMEs) regarded language barriers as the foremost barriers to cross-border procurement.(34)

(31) D.A. Hindman III and R.N. Parker, "Piggyback Contracts: The Benefits and the Limits of Shared Purchasing", Procurement Lawyer, 49, 3, p. 16.

(32) EC, "Measurement of impact of cross-border penetration in public procurement", February 2017.

(33) There are currently 24: Bulgarian, Croatian, Czech, Danish, Dutch, English, Estonian, Finnish, French, German, Greek, Hungarian, Irish, Italian, Latvian, Lithuanian, Maltese, Polish, Portuguese, Romanian, Slovak, Slovene, Spanish and Swedish.

(34) See also R. WILLIAMS QC, "Improving access for SMEs to cross-border defence procurement", PPLR, 2017, 2, NA41-NA42: "SMEs find it particularly difficult to access cross-border defence contracts due to a lack of information, administrative burdens, language barriers, cultural, legal and administrative differences between EU countries, and costs related to distance". 
Nonetheless, professionalism in public procurement - the other and related constraint considered here - is not a new concept. In the United States, the creation of a position for contract specialist, an upgrade from its previous position as purchasing agent, began in 1959. In 1970, the U.S. Comptroller General emphasized the need "to develop a competent procurement workforce with the capacity for exercising more initiative and judgement in making procurement decisions". After a series of reports and recommendations, the U.S. Congress passed the Federal Acquisition Reform Act (FARA) in 1996 which provided for the joint authority of the Administrator of the Office of Federal Procurement Policy (OFPP) and the Director of the U.S. Office of Personnel Management (OPM) in establishing the specific requirements for contracting personnel. In 1997, OPM and OFPP jointly issued the new qualification standards for contracting officials, that is, either a college degree or twenty-four semester hours of study in specified business/legal subjects for entry level positions, and, both for all senior-level positions.

In 2015, the OECD recommended the development of a procurement workforce with the capacity to continually deliver value for money efficiently and effectively by ensuring that procurement officials meet high professional standards for knowledge, practical implementation and integrity by providing a dedicated and regularly updated set of tools, for example, sufficient staff in terms of numbers and skills, recognition of public procurement as a specific profession, certification and regular trainings, integrity standards for public procurement officials and the existence of a unit or team analysing public procurement information and monitoring the performance of the public procurement system.(35)

More recently, the European Commission adopted a Recommendation on the Professionalisation of Public Procurement on October 3, 2017. The document enumerated a series of recommendations aimed at increasing the overall professionalism of contracting authorities/entities staff, and particularly focusing on policy architecture, cooperation between and within public administrations, efficiency, transparency, integrity, careers and HR management.(36) Interestingly, the Commission identified three lines of action in professionalisation: 1) developing appropriate policy architecture for professionalisation; 2) improving training and career management of procurement practitioners; and 3) providing tools and methodologies to support professional procurement practice.(37)

(35) OECD, Recommendation to the Council on Public Procurement, 2015.

(36) EC, Recommendation on the professionalisation of public procurement: Building an architecture for the professionalisation of public procurement, 3.10.2017, C(2017) 6654 final, October 2017.

(37) A. Solomonyan, "A soft tool for making public procurement more professional", PPLR, 2018, 1, NA3-NA4. 
Measures have been adopted to address these challenges, as in the case of the innovations related to the Tenders Electronic Daily (TED) common procurement vocabulary when drafting and publishing public procurement notices.(38) Cavallo Perin and co-editor Racca also emphasize the support to contracting authorities in overcoming linguistic barriers during the drafting stage of tender documents and contractual terms, while ensuring that these documents are available in different languages.(39)

In addition, new technologies have been introduced, both at the European and the national levels. As of 15 January 2016, an online machine translation service has been made available, free of charge, for all public procurement notices published in Tenders Electronic Daily (TED), which is the online version of the Supplement to the Official Journal of the EU, dedicated to European public procurement. The development of 'smart contracts' through new technology may also favor new forms of cooperation with collaborative agreements among suppliers and public administration with different legal and language background, aiming at a shared goal, i.e., the correct and prompt execution of public (smart) contracts.(40)

Tender documents offered in different languages can assure wider transparency to facilitate cooperation which will strengthen the capacity of public administrations to pursue public interests, and further the objectives of growth, innovation and integrity of the European Union.(41)

Within this framework, innovative, joint and cross-border procurement represent unique chances to reshape the relevant systems and achieve a digital transformation towards modern, innovative and sustainable procurement systems fit for the $21^{\text {st }}$ century.

\section{Conclusion}

This brings us full circle, then, to the purpose of this book: to foster critical discussion of innovation in procurement. In the case of cross-border joint procurement, as the discussion above reflects, important issues - the governments and the contracting entities which can cooperate, the legal and political

(38) R. Williams, "European Communities: proposed adoption of mandatory common procurement vocabulary", PPLR, 2002, 2, pp. 19-20.

(39) E.g., in the HAPPI project, the documents were available in the English, French and Italian languages. For further information on the HAPPI project, see also R. Cavallo PERIN and G.M. RACCA, "European Joint Cross-border Procurement and Innovation", Chapter 3 in this book.

(40) G.M. RACCA, "The role of third parties in the execution of public contracts", in Contrôles et contentieux des contrats publics / Oversight and Challanges of public contracts (L. FoLLIOT-LALLIOT and S. ToRricelli eds), Brussels, Bruylant, 2018, p. 415.

(41) EU Commission, Making Public Procurement work in and for Europe, COM(2017) 572 final, October 2017 , p. 7 . 
imperatives which will inform that procurement, and the institutional biases of the sponsoring agencies, among others - are only now being assessed. To make cross-border procurement work, those issues need to be recognized and, where possible, addressed; as the discussion above shows, and as this volume more generally shows, perspectives from other systems will, we hope, ease those solutions. 